\title{
What is driving declines of montane endemic amphibians? New insights from Mount Bamboutos, Cameroon
}

\author{
A. M. Tchassem F., T. M. Doherty-Bone, M. M. Kameni N. \\ W. P. Tapondjou N., J. L. Tamesse and L. N. Gonwouo
}

\begin{abstract}
Amphibians on African mountains are threatened by habitat loss and fragmentation, pollution, disease and climate change. In particular, there have been recent reports of declines of montane endemic frogs in Cameroon. Mount Bamboutos, although home to numerous species of endemic amphibians, has no official protection and its amphibian populations have so far not been studied quantitatively. We surveyed frog assemblages on this mountain along a gradient of forest modification over a 2-year period. Through visual encounter surveys stratified across forest and farmland, we found that threatened montane amphibian species are closely associated with forested areas, particularly the Critically Endangered Leptodactylodon axillaris and Endangered Leptodactylodon perreti, Astylosternus ranoides and Cardioglossa oreas. Using the updated inventory of amphibians, which includes species with broader ranges across Africa, we found $69 \%$ of amphibian species on Mount Bamboutos to be threatened. We did not record several species present in historical records, which suggests they may have disappeared from this mountain, including Cardioglossa pulchra, Phrynobatrachus steindachneri, Phrynobatrachus werneri, Sclerophrys villiersi, Werneria bambutensis and Wolterstorffina mirei. The pattern of change detected in the amphibian community is consistent with declines on other mountains in the country, with a loss of Phrynobatrachus, Werneria and Cardioglossa spp., but persistence of Astylosternus, Arthroleptis and Leptodact$y$-lodon. The observed relationships of land-use patterns and amphibian diversity suggest that ongoing land-use changes could extirpate the remaining montane endemic frog species, particularly L. axillaris and L. perreti.
\end{abstract}

A. M. TChassem F.* (Corresponding author), M. M. Kameni N. ${ }^{*}$ and L. N. Gonwouo $^{*}$ Laboratory of Zoology, Faculty of Sciences, University of Yaoundé I, P.O. Box 812, Yaoundé, Cameroon

E-mail arnaudtchassem@yahoo.fr

T. M. Doherty-Bone Conservation Research \& Action for Amphibians of Cameroon, Royal Zoological Society of Scotland, Edinburgh, UK

W. P. TAPondjou N.* Department of Ecology and Evolutionary Biology, University of Kansas, Lawrence, USA

J. L. TAMesse Department of Biological Science, Higher Teacher Training College, Yaoundé, Cameroon

${ }^{*}$ Also at: Cameron Herpetology-Conservation Biology Foundation, Yaoundé, Cameroon

Received 16 June 2018. Revision requested 9 August 2018.

Accepted 20 November 2018. First published online 3 December 2019.
Preserving a network of connected forest patches is therefore critical to save the endemic amphibians of Mount Bamboutos.

Keywords Africa, amphibians, anurans, Cameroon, caecilians, endemic species, forest degradation, mountains

Supplementary material for this article is available at https://doi.org/10.1017/So030605318001448

\section{Introduction}

mphibians are threatened globally, with over one-third A of all known species at risk of extinction and half showing population declines (Stuart et al., 2004; IUCN, 2017). Threats include habitat alteration, loss and fragmentation, pollution, overexploitation, disease, invasive species, climate change and combinations of these factors (Beebee \& Griffiths, 2005). Habitat loss, degradation and fragmentation, such as through conversion to and intensification of agriculture (Stuart et al., 2004), can leave amphibians vulnerable to predation and desiccation and thus are important drivers of amphibian declines (Cushman, 2006). Conversion to agriculture is also often accompanied by use of agrochemicals and other pollutants that have the potential to negatively affect amphibians (Mann et al., 2009).

Responses of African amphibians to habitat change are poorly understood because of a paucity of studies across the continent, especially in forested areas (Lawson \& Klemens, 2001; Gardner et al., 2007a; Brito, 2008). However, some studies have been carried out across the continent, showing that amphibian diversity and abundance differ between primary forest, selectively logged forests and forestry plantations in Côte d'Ivoire, Madagascar and Ghana (Ernst et al., 2006; Hillers et al., 2008; Ofori-Boateng et al., 2013; Riemann et al., 2017), and between natural wooded savannah and areas converted for agriculture in East Africa (Gardner et al., 2007b). Some African amphibian species are threatened because their sole habitat is subject to development, such as Nimbaphrynoides occidentalis, which is under threat from mining activities (Sandberger-Loua et al., 2016). The impact of agrochemicals and other pollutants, another major threat besides habitat loss, has been rarely studied in Africa (Schiesari et al., 2007), with some exceptions in Nigeria (Akani et al., 2004). 
A significant number of African amphibians endemic to individual mountains or mountain ranges are threatened with extinction because of their small range sizes (Poynton et al., 2006; Largen \& Spawls, 2010). For example, $88 \%$ of Cameroonian amphibians categorized as Vulnerable, Endangered or Critically Endangered on the IUCN Red List are restricted to highland areas (IUCN, 2017). Threats to Afromontane endemic amphibians have rarely been quantified, although such studies are required urgently as these regions are undergoing both rapid development and climate change (Beniston et al., 1996; Burgess et al., 2007). In addition to the threats posed by habitat loss and pollution, less understood factors such as pathogens are correlated with the recently reported declines of amphibians in Cameroonian mountain ranges (Hirschfeld et al., 2016). Research into the status of and threats to African montane amphibians is therefore urgently needed.

The amphibian fauna of Cameroon is relatively wellstudied (Perret, 1966; Amiet, 2012), and 53 species have been assessed as threatened with extinction $(25.8 \%$; IUCN, 2017). Many of these occur in the country's highlands, and the majority are montane endemics (Gartshore, 1986; Bergl et al., 2007). Detailed inventories have been compiled and updated for several Cameroonian mountains in the past decades (Amiet, 1977, 1980; Herrmann et al., 2005, 2007; Doherty-Bone \& Gvoždík, 2017), but not for the more severely deforested mountains in the Bamenda Highlands, particularly Mount Bamboutos. This mountain hosts several threatened amphibian species endemic to the Cameroon Volcanic Line, most notably the Critically Endangered egg frog Leptodactylodon axillaris. The species is possibly endemic to this particular mountain (Amiet, 1980); although specimens suspected to be $L$. axillaris have been found on nearby Mount Oku, their identity has yet to be confirmed (Doherty-Bone \& Gvoždík, 2017). Other rare species recorded from this mountain include the Endangered Werneria bambutensis and Wolterstorffina mirei (Perret, 1972; Gartshore, 1986). Despite harbouring amphibian species of conservation concern, Mount Bamboutos is not officially protected (Bergl et al., 2007). The objectives of our study were to (1) update the amphibian inventory of this mountain, (2) assess the trend of remaining amphibian populations, and (3) identify habitat requirements of amphibian species to gain a better understanding of the threats posed by deforestation and agricultural encroachment.

\section{Study area}

Mount Bamboutos is situated in western Cameroon (Fig. 1), encompassing c. $340 \mathrm{~km}^{2}$, mostly at an altitude of $>1,600 \mathrm{~m}$ (Bergl et al., 2007). The massif is the third tallest mountain of the Cameroon Volcanic Line after Mounts Cameroon and Oku (Gountié Dedzo et al., 2013). The climate of Mount Bamboutos is characterized by dry (NovemberMarch) and wet (April-October) seasons. Mean annual rainfall is $1,918 \mathrm{~mm}$ and mean temperature is $18.9^{\circ} \mathrm{C}$ at an altitude of 2,700 $\mathrm{m}$ (Kengni et al., 2009). The natural vegetation is montane forest and grassland, much of which has been replaced by crop fields, Eucalyptus plantations or pasture. Human communities living on the mountain include Fulani (sometimes referred to as Mbororo) and Mbouda peoples.

\section{Methods}

\section{Field surveys}

To obtain an updated assessment of the amphibian species composition, status and habitat requirements on Mount Bamboutos, we conducted field surveys every 3 months during March 2014-May 2016, with a total of 10 surveys across all seasons. Surveys were stratified between forest, grassland and cultivated areas. We designated six discrete plots per land-use type, with a minimum distance of $486 \mathrm{~m}$ between them, which we revisited during each survey period. We chose sample sites at an altitude of $2,000-2,601 \mathrm{~m}$, to focus on land-use effects and minimize variation caused by altitude. Because the landscape on Mount Bamboutos is fragmented, we could not locate plots of a homogenous land-use type that were large enough to allow for a $500 \mathrm{~m}$ buffer from the plot boundary to eliminate possible edge effects (sensu Gardner et al., 2007a). We thus interpreted survey data with caution, notably treating single occurrences of a species as potential vagrants (Barlow et al., 2010). At each survey we recorded number of surveyors, search time, elevation, species and number of individuals of each species observed.

We conducted day and night-time surveys in the designated sample sites using visual and acoustic encounter surveys. This involved searching of microhabitats, such as lifting rocks and logs, peeling bark from trees, moving fallen debris and inspecting tree stems during the day (07.00-12.00) and at night (19.00-00.00) along streams and ponds, and in the surrounding vegetation (Crump \& Scott, 1994; Rödel \& Ernst, 2004). Individual anurans were also located by their vocalization. Anurans were captured by hand. Local farmers were invited to alert AMTF to any amphibians they encountered, and some volunteered amphibian specimens to the field researchers. These specimens were included in the final species inventory, but not the habitat use analysis. Specimens were identified to species level in the field and released immediately. Voucher specimens were collected for later examination when species identity was uncertain, or for studies of systematic biology. Collection was restricted to no more 


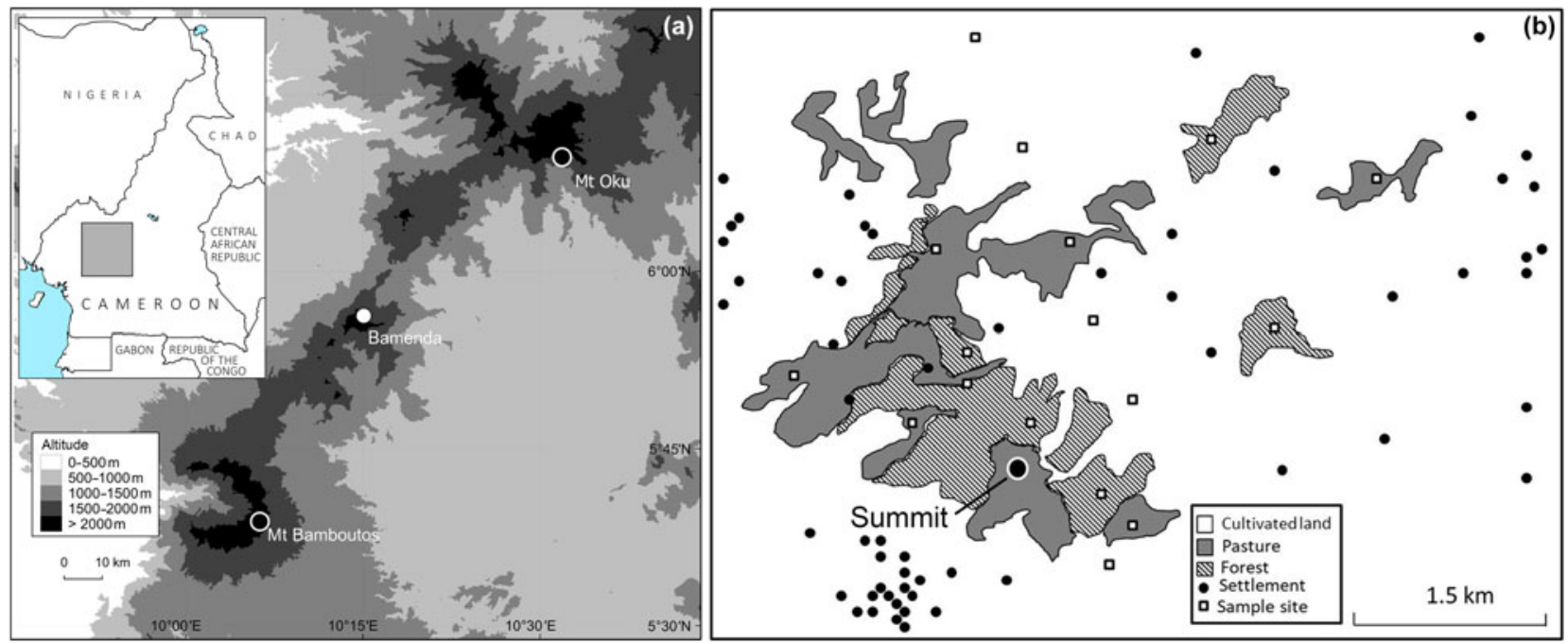

FIG. 1 (a) Topography of the Bamenda Highlands and (b) location of survey sites on Mount Bamboutos.

than five specimens per putative species, totalling 29 specimens of 10 species. Voucher specimens were euthanized using an overdose of tricaine mesylate or chlorobutanol.

To understand habitat conversion and intensity of land use, we qualitatively monitored land management during the survey, which included semi-structured interviews with local farmers on their use of the landscape. We questioned a total of 195 farmers, including 28 from the Fulani community (21 women, 7 men) and 167 Mbouda (8o women, 115 men), on their creation of farms and their use of forest products and agrochemicals (see Supplementary Material 1 for full questionnaire).

\section{Data analysis}

We compared the data collected during our study to previous surveys (Perret, 1972; Amiet, 1977, 1980; Gartshore, 1986; Hirschfeld et al., 2016), cross-checked the final species inventory against the IUCN Red List of Threatened Species, and calculated the proportion of threatened species following Böhm et al. (2013). To assess the value of different habitats for amphibian community composition (beta diversity), we performed a PERMANOVA analysis, using function adonis in the $R$ 3.3.2 package vegan ( $\mathrm{R}$ Core Team, 2016), testing the significance of the Bray-Curtis dissimilarity based on 999 permutations (Anderson, 2001; Riemann et al., 2017). Square root transformed amphibian species abundance data were subjected to ordination analysis using non-metric dimensional scaling plots of Bray-Curtis dissimilarities, with function metaMDS in vegan, to view similarities in amphibian community structure between land-use types. We used function simper in vegan to identify the species contributing most to the differences between land-use types (Clarke, 1993). Generalized linear models, with $R$ function $g l m$, were used to evaluate the influence of habitat (forest, crop fields, pasturegrassland) on the relative abundance of species, notably those observed on at least five separate occasions, to ensure the model was informative. This method is more robust compared to more commonly used non-parametric tests (such as Kruskal-Wallis tests). Generalized linear models accommodate the error distribution of the data, in this case count data (number of individuals), which typically fit a Poisson distribution (O'Hara \& Kotze, 2010). We incorporated parameters such as season, year and elevation in the generalized linear models to assess the influence of potential confounding factors on the response variable (abundance of frogs). We then applied an information criterion analysis to the models and used the resulting Akaike's information criterion (AIC) to assess the best-performing model based on incorporation of the potentially competing explanatory factors (Mazerolle, 2006).

\section{Results}

\section{Amphibian diversity and conservation assessment}

We found a total of 266 individuals of 10 amphibian species during the 2014-2016 survey period (Table 1). Ten specimens were volunteered by farmers: one caecilian Herpele squalostoma, one Astylosternus ranoides, two A. rheophilus and six Leptopelis nordequatorialis, originating from farms adjacent to forest patches. The total species inventory of Mount Bamboutos based on our surveys and published information comprises 16 species (Table 1), although we found only 10 species in our 2014-2016 surveys. We did not record Cardioglossa pulchra, Phrynobatrachus steindachneri, Phrynobatrachus werneri, Sclerophrys villiersi, Werneria 
TABLE 1 An updated amphibian species inventory for Mount Bamboutos.

\begin{tabular}{|c|c|c|c|}
\hline Species & $\begin{array}{l}\text { IUCN Red } \\
\text { List category }\end{array}$ & Endemicity $^{2}$ & Sources \\
\hline Arthroleptis cf. perreti & EN & BamH & This study \\
\hline Astylosternus ranoides & $\mathrm{EN}$ & $\mathrm{BamH}$ & Amiet (1977); this study \\
\hline Astylosternus rheophilus & VU & $\mathrm{CNH}$ & Amiet (1977); Hirschfeld et al. (2016); this study \\
\hline Cardioglossa oreas & $\mathrm{EN}$ & $\mathrm{BamH}$ & Amiet (1972); this study \\
\hline Cardioglossa pulchra & $\mathrm{EN}$ & $\mathrm{CNH}$ & Hirschfeld et al. (2016) \\
\hline Leptodactylodon axillaris & CR & $\mathrm{BamH}$ & $\begin{array}{l}\text { Amiet (1980); Cruz et al. (2013); } \\
\text { Hirschfeld et al. (2016); this study }\end{array}$ \\
\hline Leptodactylodon perreti & $\mathrm{EN}$ & $\mathrm{BamH}$ & Amiet (1980); this study \\
\hline Leptopelis nordequatorialis & LC & $\mathrm{CNH}$ & This study \\
\hline Sclerophrys maculata & LC & PanAfr & Hirschfeld et al. (2016); this study \\
\hline Sclerophrys villiersi & $\mathrm{EN}$ & $\mathrm{CH}$ & Hirschfeld et al. (2016) \\
\hline Werneria bambutensis & $\mathrm{EN}$ & $\mathrm{CH}$ & Amiet (1972); Hirschfeld et al. (2016) \\
\hline Wolterstorffina mirei & $\mathrm{EN}$ & BamH & Perret (1972); Hirschfeld et al. (2016) \\
\hline Phrynobatrachus steindachneri & $\mathrm{VU}$ & $\mathrm{CNH}$ & Mertens (1968); Hirschfeld et al. (2016) \\
\hline Phrynobatrachus werneri & LC & $\mathrm{CNH}$ & Gartshore (1986) \\
\hline Ptychadena cf. mascariensis 'D' & LC & PanAfr & This study \\
\hline Herpele squalostoma & LC & CongB & This study \\
\hline
\end{tabular}

${ }^{1}$ LC, Least Concern; VU, Vulnerable; EN, Endangered; CR, Critically Endangered.

${ }^{2} \mathrm{PanAfr}$, species with pan-African ranges; CongB, species with ranges restricted to Congo Basin forest; $\mathrm{CNH}$, species restricted to highlands of Cameroon and Nigeria; $\mathrm{CH}$, species restricted to the highlands of Cameroon; BamH, species restricted to the Bamenda Highlands of Cameroon (includes Mounts Bamboutos, Oku, Lefo and Mbam).

bambutensis and Wolterstorffina mirei. These are montane endemic species, and were last observed on Mount Bamboutos in 2006 (Hirschfeld et al., 2016), except for P. werneri (last observed in 1984; Gartshore, 1986) and S. villiersi (last observed in 2004; Hirschfeld et al., 2016). All but one of the species not located are categorized as threatened (one Vulnerable, four Endangered) on the IUCN Red List, and $69 \%$ of the species in the complete inventory are categorized as threatened. In addition to the caecilian $H$. squalostoma, we found three species not previously recorded on the mountain: $L$. nordequatorialis, Ptychadena cf. mascariensis ' $\mathrm{D}$ ' and a frog corresponding to Arthroleptis perreti, similar to specimens observed on Mount Oku. However, the species accumulation curve over time does not show a plateau, indicating the species inventory may be incomplete (Fig. 2).

\section{Field surveys}

Based on 389 surveyor hours divided equally amongst landuse types, the majority of amphibians were found in forests (180 individuals) followed by agricultural areas (65 individuals) and pasture (three individuals). Most species (eight) were found in forest, four species in cultivated areas and three in pasture (Table 2). The Endangered L. perreti and Critically Endangered L. axillaris were found exclusively in forest habitats. Leptodactylodon axillaris was found in only one particular forest patch at 2,450 m altitude, sharing breeding sites in small streams with $L$. perreti. Surveys of one particular stream in a now deforested area, where L. axillaris had been recorded in 2006, failed to detect this species (Cruz et al., 2013). We observed the Endangered A. ranoides on only four separate occasions and found that it was marginally more abundant in forest than cultivated land, with fewer observations in pasture. Where the species was recorded in pasture areas, it occurred always within $50 \mathrm{~m}$ of the nearest forest edge. The Vulnerable A. rheophilus and Endangered Cardioglossa oreas were exclusively found in forest.

Amphibian community structure varied significantly across land-use types (PERMANOVA: $\mathrm{P}=0.001$ ), with nonmetric dimensional scaling of community dissimilarity showing little overlap of amphibian communities between the three habitat types (Fig. 3). Analysis with simper showed that species contributing most to dissimilarities between forest and cultivated land were $L$. perreti and $L$. nordequatorialis, whereas between pasture and forest these were L. perreti, S. maculata and A. ranoides (Table 3). Between pasture and cultivated land, $L$. nordequatorialis, $P$. cf. mascariensis ' $D$ ' and $A$. ranoides contributed most to the dissimilarity.

For those species with sufficient records for generalized linear modelling (i.e. observed on at least five occasions), habitat had a significant influence on their occurrence (L. perreti, A. rheophilus, L. nordequatorialis and P. cf. mascareniensis ' $D$ '; Table 4). Season and elevation also significantly influenced the model for $L$. perreti and $L$. nordequatorialis. Habitat, season and elevation combined provided the model with the best fit (i.e. the lowest AIC) for $L$. perreti, with $\triangle \mathrm{AIC}=3$ compared to a model that 


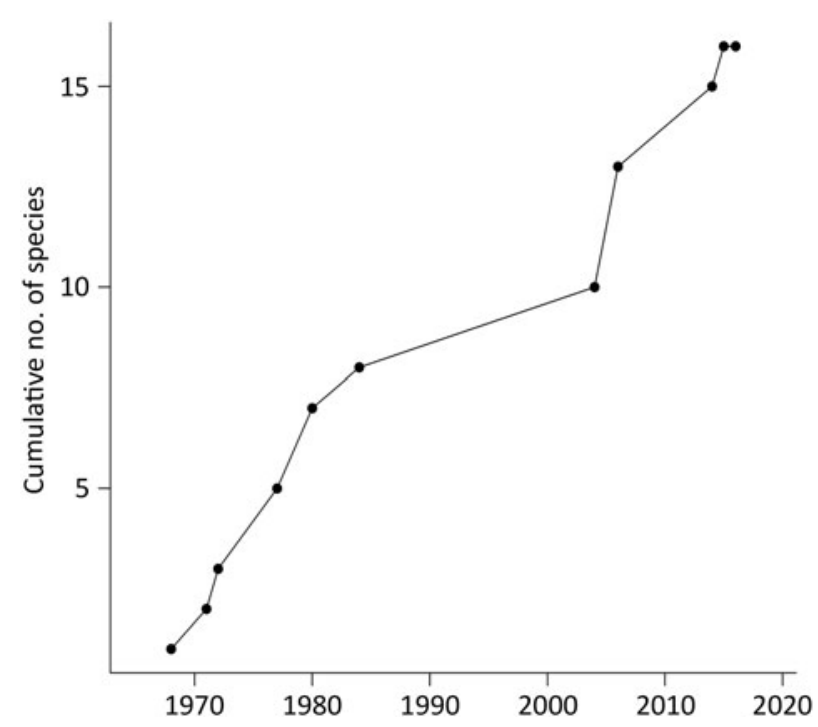

FIg. 2 Species accumulation curve for amphibians on Mount Bamboutos based on historical and contemporary records.

TABLE 2 Summary of amphibian species (total per habitat type across all survey techniques) encountered during this study (2014-2016).

\begin{tabular}{llll}
\hline Species & $\begin{array}{l}\text { Cultivated } \\
\text { land }\end{array}$ & Pasture & Forest \\
\hline A. cf. perreti & 0 & 1 & 0 \\
A. ranoides & 2 & 2 & 4 \\
A. rheophilus & 0 & 0 & 18 \\
C. oreas $_{\text {H. } \text { squalostoma }}$ & 0 & 0 & 3 \\
L. axillaris & 0 & 0 & 1 \\
L. perreti & 0 & 0 & 4 \\
L. nordequatorialis & 0 & 0 & 163 \\
P. mascareniensis $_{\text {S. } \text { maculata }}$ & 45 & 0 & 3 \\
Total & 16 & 0 & 1 \\
No. of species $^{1}$ & 1 & 1 & 0 \\
Mean no. of specimens $^{\text {per sampling event }}{ }^{1}$ & 65 & 4 & 197 \\
\hline
\end{tabular}

${ }^{1}$ Data from visual encounter surveys (equal survey effort per habitat) only.

included only habitat. For the other three species the bestperforming model included only habitat. Year of survey had little influence on the significance or fit of the models, suggesting stability over the 2-year survey period.

\section{Human use of the landscape}

We frequently observed creation of new crop farms throughout 2014-2016, up to an altitude of 2,450 $\mathrm{m}$ and preceded by the clearance of forest. We also noted a shift from subsistence-oriented (bananas, raffia palms, fruit trees, yams) to cash-crop oriented (carrots, onions, potatoes, maize, beans,

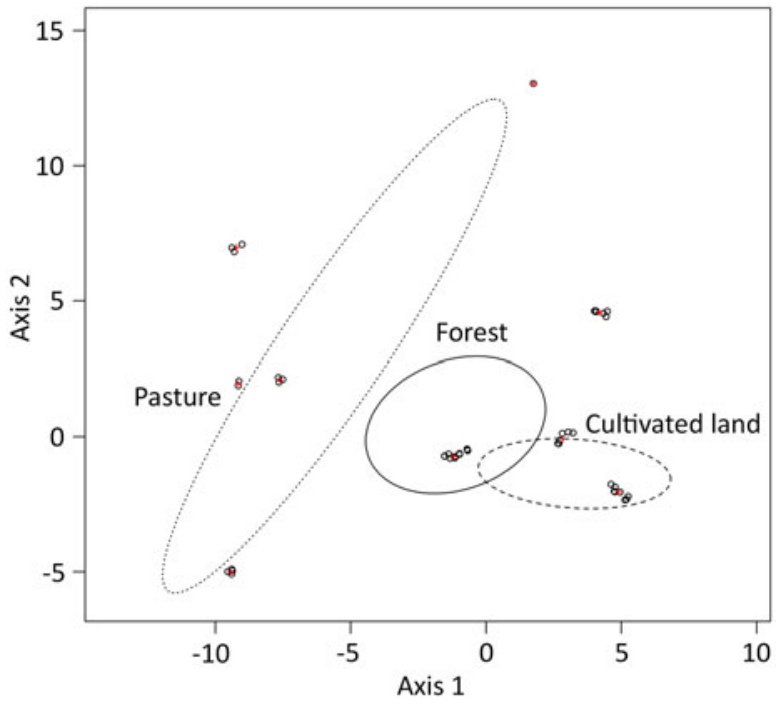

FIG. 3 Non-metric dimensional scaling plot of amphibian community structure divided by land-use type on Mount Bamboutos, based on visual encounter surveys with equal search effort per land-use type (Stress = 0.00oo6; PERMANOVA: $\mathrm{P}=0.001)$. Ellipses show groupings of sites based on class standard deviations of species assemblages constrained by land use.

eucalyptus) farming. All Mbouda farmers surveyed now practise agriculture primarily as a commercial activity, whereas Fulani are subsistence farmers. Informants (Fulani and Mbouda; $\mathrm{n}=78$ ) claimed that the economic importance of small-scale forest use had diminished by $90 \%$ over the past decade. Their forest use included the extraction of both timber and non-timber forest products (e.g. bamboo for house construction), and was declining relative to food crop production. Interviewees perceived that encroachment of cultivation had been exacerbated by new families settling on Mount Bamboutos over the previous decade. This landuse change was accompanied by increased use of agrochemicals, which we observed across cultivated areas following the planting of seeds. Chemicals used were predominately pesticides against weeds and potato blight (see Table 5 for a list of chemicals); we did not observe use of fertilizers. Pesticides were frequently prepared within or next to streams, without protective equipment, and chemicals often spilt from the containers. The majority of interviewed farmers $(71 \%)$ had not received a basic education and are thus unlikely to understand product labels on packaging relating to recommended dosages and safety measures. Most local people interviewed (71\%) expressed favourable attitudes towards conservation, but stated financial support was necessary to enable them to abstain from clearing natural habitats. We observed diversion of water from streams in the forest at eight sites, mostly at 2,250-2,600 m altitude. The water is used to irrigate fields and is extracted with suction pipes, with a particularly high number of pipes 
TABLE 3 Results of the similarity percentage analysis (using simper), showing the importance of dissimilarity for different amphibian species by habitat type based on visual encounter surveys on Mount Bamboutos.

\begin{tabular}{|c|c|c|c|c|}
\hline \multirow{2}{*}{$\frac{\text { Taxon }}{\text { Forest vs cultivated land }}$} & \multicolumn{2}{|c|}{ Mean \pm SD individuals per survey } & \multirow[t]{2}{*}{$\begin{array}{l}\text { Proportional } \\
\text { contribution } \\
\text { to dissimilarity }\end{array}$} & \multirow[t]{2}{*}{$\begin{array}{l}\text { Cumulative } \\
\text { proportional } \\
\text { contribution }\end{array}$} \\
\hline & Forest & Cultivated land & & \\
\hline L. perreti & $2.26 \pm 1.81$ & $0 \pm 0$ & 0.44 & 0.44 \\
\hline L. nordequatorialis & $0 \pm 0$ & $0.60 \pm 1.19$ & 0.29 & 0.73 \\
\hline P. cf. mascariensis ' $\mathrm{D}$ ' & $0.01 \pm 0.12$ & $0.22 \pm 0.68$ & 0.13 & 0.86 \\
\hline A. rheophilus & $0.22 \pm 0.61$ & $0 \pm 0$ & 0.07 & 0.93 \\
\hline A. ranoides & $0.06 \pm 0.33$ & $0.03 \pm 0.24$ & 0.03 & 0.96 \\
\hline Forest vs pasture & Forest & Pasture & & \\
\hline L. perreti & $2.26 \pm 1.81$ & $0 \pm 0$ & 0.49 & 0.50 \\
\hline A. ranoides & $0.06 \pm 0.33$ & $0.03 \pm 0.24$ & 0.16 & 0.66 \\
\hline S. maculata & $0 \pm 0$ & $0.01 \pm 0.12$ & 0.10 & 0.77 \\
\hline A. cf. perreti & $0 \pm 0$ & $0.01 \pm 0.12$ & 0.10 & 0.88 \\
\hline A. rheophilus & $0.22 \pm 0.61$ & $0 \pm 0$ & 0.08 & 0.95 \\
\hline Pasture vs cultivated land & Pasture & Cultivated land & & \\
\hline L. nordequatorialis & $0 \pm 0$ & $0.60 \pm 1.19$ & 0.37 & 0.38 \\
\hline A. ranoides & $0.03 \pm 0.24$ & $0.03 \pm 0.24$ & 0.18 & 0.57 \\
\hline P. cf. mascariensis 'D' & $0 \pm 0$ & $0.22 \pm 0.68$ & 0.17 & 0.74 \\
\hline S. maculata & $0.01 \pm 0.12$ & $0.01 \pm 0.12$ & 0.12 & 0.87 \\
\hline A. cf. perreti & $0.01 \pm 0.12$ & $0 \pm 0$ & 0.12 & 1.00 \\
\hline
\end{tabular}

used during the dry season (mean of 15 pipes per stream). Only the Fulani community graze livestock in the area, and livestock herders set bushfires in pasture areas during January-March. The practice aims to promote regrowth of new grass at the onset of the wet season. Interviewees from the Fulani community, which is dominated by livestock owners, were reluctant to answer questions on the use of fire because the practice is illegal (Décret No 95/531/PM DU 23 Août, 1995).

\section{Discussion}

We reappraised the amphibian diversity of Mount Bamboutos through both examining the published literature and undertaking a multi-season survey over 2 years. We found additional species not previously recorded on the mountain, but also noted a decline in several montane endemic amphibian species, consistent with reports from other mountains in the highlands of Cameroon (Hirschfeld et al., 2016). An assessment of habitat requirements suggests that the remnant forest of Mount Bamboutos is a key habitat for the remaining species of conservation concern, although it is substantially reduced in size and of degraded quality. Rapid encroachment of cultivated areas is accompanied by water abstraction, use of agrochemicals, livestock grazing and fire, factors that exacerbate long-term degradation of remnant amphibian habitat.

The total amphibian species inventory of Mount Bamboutos is low (16 species) in comparison to neighbouring
Mount Oku (50 species; Doherty-Bone \& Gvoždik, 2017), despite Bamboutos being larger $\left(340 \mathrm{~km}^{2}\right)$ than Oku $\left(200 \mathrm{~km}^{2}\right.$; Bergl et al., 2007). It is possible that during the historical agricultural encroachment into the forest and grasslands of Mount Bamboutos, many species were extirpated prior to the arrival of amphibian biologists. In addition, the degraded sites are at high altitudes, making it unlikely that colonization by low- and mid-elevation species could compensate for the loss of montane and forest-adapted species. More sampling is needed at lower altitudes on Mount Bamboutos to include mid- and lowelevation species in the inventory and provide a more accurate calculation of the proportion of threatened species.

As observed on Mount Oku in the North-West Region and Mount Manengouba in the South-West and Littoral Regions during 2011-2017 (Hirschfeld et al., 2016; Doherty-Bone \& Gvoždik, 2017), we did not locate $P$. steindachneri (which has since been found to consist of a species complex that includes P. jimzimkusi; Zimkus \& Gvoždik, 2013) in our surveys. Prior to its reported decline on these other mountains, this species was abundant. Phrynobatrachus werneri is another species of the same genus that had previously been recorded on Mount Bamboutos, but has not been observed there in recent surveys. Doherty-Bone \& Gvoždik (2017) have proposed that the conservation status of these Phrynobatrachus species should be reassessed and moved to a higher extinction risk category. Although we observed C. oreas, we did not observe C. pulchra or the mountain toads W. bambutensis and $W$. mirei. The causes of this are unclear, but these species 
TABLE 4 Generalized linear models comparing parameters influencing abundance of amphibian species on Mount Bamboutos, showing degrees of freedom (df), deviance residual, P-value, Akaike information criterion (AIC) and difference of AIC from the best-performing model.

\begin{tabular}{|c|c|c|c|c|c|}
\hline Model parameters & $\mathrm{df}$ & Deviance residual & $\mathrm{P}$-value & AIC & $\Delta \mathrm{AIC}$ \\
\hline \multicolumn{6}{|l|}{$\overline{\text { Leptodactylodon perreti }}$} \\
\hline Habitat $\times$ Elevation $\times$ Season $\times$ Year & 87 & 109.47 & 0.99 & 299 & 9 \\
\hline Habitat $\times$ Elevation $\times$ Season & 95 & 117.14 & 0.99 & 290 & 0 \\
\hline Habitat $\times$ Elevation & 99 & 129.77 & 1.00 & 295 & 5 \\
\hline Habitat $\times$ Season & 100 & 130.18 & 0.99 & 293 & 3 \\
\hline Season $\times$ Elevation & 101 & 222.03 & 0.02 & 383 & 93 \\
\hline Habitat $\times$ Year & 100 & 133.78 & 0.99 & 297 & 7 \\
\hline Habitat & 102 & 133.88 & $<0.001$ & 293 & 3 \\
\hline Elevation & 103 & 229.59 & $<0.001$ & 387 & 97 \\
\hline Season & 103 & 252.23 & 0.03 & 409 & 119 \\
\hline Year & 103 & 256.22 & 0.42 & 413 & 123 \\
\hline \multicolumn{6}{|l|}{ Astylosternus rheophilus } \\
\hline Habitat $\times$ Elevation $\times$ Season $\times$ Year & 87 & 55.34 & 0.99 & 115 & 21 \\
\hline Habitat $\times$ Elevation $\times$ Season & 95 & 61.22 & 0.99 & 105 & 11 \\
\hline Habitat $\times$ Elevation & 99 & 64.09 & 1.00 & 100 & 6 \\
\hline Habitat $\times$ Season & 100 & 61.43 & 0.99 & 96 & 2 \\
\hline Season $\times$ Elevation & 101 & 71.95 & 0.54 & 104 & 10 \\
\hline Habitat & 102 & 64.01 & $<0.01$ & 94 & 0 \\
\hline Elevation & 103 & 75.16 & 0.32 & 103 & 9 \\
\hline Season & 103 & 73.74 & 0.12 & 102 & 8 \\
\hline Year & 103 & 76.16 & 0.95 & 104 & 10 \\
\hline \multicolumn{6}{|l|}{ Leptopelis nordequatorialis } \\
\hline Habitat $\times$ Elevation $\times$ Season $\times$ Year & 87 & 38.95 & 0.99 & 123 & 16 \\
\hline Habitat $\times$ Elevation $\times$ Season & 95 & 45.62 & 0.99 & 114 & 7 \\
\hline Habitat $\times$ Elevation & 99 & 51.19 & 1.00 & 111 & 4 \\
\hline Habitat $\times$ Season & 100 & 48.59 & 0.99 & 107 & 0 \\
\hline Season $\times$ Elevation & 101 & 138.70 & 0.54 & 195 & 88 \\
\hline Habitat & 102 & 52.95 & $<0.001$ & 107 & 0 \\
\hline Elevation & 103 & 144.24 & $<0.001$ & 196 & 87 \\
\hline Season & 103 & 151.63 & $<0.01$ & 204 & 97 \\
\hline Year & 103 & 160.54 & 0.70 & 212 & 105 \\
\hline \multicolumn{6}{|l|}{ Ptychadena cf. mascariensis ' $\mathrm{D}$ ' } \\
\hline Habitat $\times$ Elevation $\times$ Season $\times$ Year & 87 & 31.04 & 0.99 & 91 & \\
\hline Habitat $\times$ Elevation $\times$ Season & 95 & 35.43 & 0.99 & 80 & 1 \\
\hline Habitat $\times$ Elevation & 99 & 45.54 & 0.98 & 82 & 3 \\
\hline Habitat $\times$ Season & 100 & 46.81 & 0.18 & 81 & 2 \\
\hline Season $\times$ Elevation & 101 & 72.61 & $<0.01$ & 105 & 26 \\
\hline Habitat & 102 & 49.12 & $<0.001$ & 79 & 0 \\
\hline Elevation & 103 & 82.33 & 0.87 & 111 & 32 \\
\hline Season & 103 & 80.77 & 0.20 & 109 & 29 \\
\hline Year & 103 & 82.04 & 0.57 & 110 & 30 \\
\hline
\end{tabular}

have also declined on Mounts Oku and Manengouba (Hirschfeld et al., 2016; Doherty-Bone \& Gvoždik, 2017). The decline of anurans on Oku and Manengouba coincided with an increased prevalence of amphibian chytrid fungus Batrachochytrium dendrobatidis (Hirschfeld et al., 2016). This pathogen was also found on one specimen of Astylosternus sp. in 2013, after retrospective sampling of 46 museum specimens collected during 2004-2006 on Mount Bamboutos (Hirschfeld et al., 2016). Batrachochytrium dendrobatidis was first recorded in eastern and southern Cameroon in 1933, which indicates that if it caused the decline it would be through an endemic emergence induced by changes in environmental conditions (Hirschfeld et al., 2016). The role of climate change in this emergence is unclear, although evidence from Cameroonian mountains suggests upslope displacement of mountain frogs and population declines following climatic extremes (Doherty-Bone, 2017).

The observation of the caecilian H. squalostoma, a species known from low to mid elevations (1,140 m; Herrmann et al., 2005), provides the highest elevational record to date for this species, at 2,000 $\mathrm{m}$. The species occurs in both forested and disturbed areas, including intensively cultivated and urban 
TABLE 5 Agrochemicals commonly used by farmers on Mount Bamboutos.

\begin{tabular}{|c|c|c|}
\hline Chemicals & Target crop & Target pest \& usage \\
\hline \multicolumn{3}{|l|}{ Fungicides } \\
\hline \multirow[t]{5}{*}{ Penncozeb $80 \mathrm{WP}$ or Cleanzup Blue $80 \mathrm{WP}$} & Seed potatoes & $\begin{array}{l}\text { Disease control; applied every } 10 \text { days throughout the crop season } \\
\text { by ground boom }\end{array}$ \\
\hline & Tomatoes & Anthracnose fungus \\
\hline & Onions & Onions leaf blight (leaf spot) \\
\hline & Celery & $\begin{array}{l}\text { Regular applications at 3-5 day intervals in plant beds from first } \\
\text { emergence of plants until plants are planted out in field }\end{array}$ \\
\hline & Carrots & Control of various diseases \\
\hline \multicolumn{3}{|l|}{ Herbicides } \\
\hline Agil 100 EC & Carrots & Broad-spectrum control of annual \& perennial grass weeds \\
\hline Cleanfarm $360 \mathrm{SL}$ & $\begin{array}{l}\text { Carrots, } \\
\text { potatoes }\end{array}$ & Control of weeds \& insects pests \\
\hline \multicolumn{3}{|l|}{ Insecticides \& nematicides } \\
\hline $\begin{array}{l}\text { Furadent Super } 10 \text { G, Vydate } 10 \text { G, Bastion Super } \\
\quad \text { \& Rugby } 10 \mathrm{G}\end{array}$ & $\begin{array}{l}\text { Celery, } \\
\text { carrots, } \\
\text { potatoes, } \\
\text { onions }\end{array}$ & Insect eggs \& larvae \\
\hline
\end{tabular}

locations (Kouete et al., 2012; T.M. Doherty-Bone \& L.N. Gonwouo, unpubl. data). Cameroonian caecilians at high elevations typically belong to the genus Crotaphatrema (Doherty-Bone et al., 2011). The individual found during our survey is not a misidentified Crotaphatrema sp. (the number of annuli suggests it is H. squalostoma; Wilkinson et al., 2006). It is possible that $H$. squalostoma is either tolerant of the climate at higher elevations, or that the climate on Mount Bamboutos is changing and thus now accommodates species adapted to lowland conditions.

This is the first quantitative study of the value of various land-use types for amphibians in the highlands of Cameroon. We found that several montane endemic frog species appear to be sensitive to forest loss, especially when forest is converted for intensive agricultural production. This included species that were hypothesized to be relatively resilient to forest loss, such as A. rheophilus (Doherty-Bone \& Gvoždik, 2017). Absence of this species in agricultural areas could therefore be caused by aspects of land management such as use of agrochemicals and fire, and replacement of natural vegetation by crop monocultures. We also observed that species adapted to high montane grasslands, notably L. nordequatorialis (Gartshore, 1986; endemic to highlands of Cameroon and Nigeria), can survive in agricultural areas: we found more individuals of $L$. nordequatorialis in cultivated areas than in grasslands on Mount Bamboutos. However, the species' vulnerability to conversion of montane grassland to cultivation should be more thoroughly assessed, particularly its ability to tolerate agrochemicals. Other species found in cultivated areas were those that are distributed widely across Africa, such as the toad S. maculata and grass frog $P$. cf. mascariensis ' $\mathrm{D}$ '. This phenomenon is typical for forest disturbance, particularly in the tropics, where specialized species with small ranges are replaced by generalized species with broad ranges (Ernst et al., 2006; Ofori-Boateng et al., 2013).

We found few amphibians in pasture, and the absence of montane endemic species such as Astylosternus, Cardioglossa and Leptodactylodon sp. was particularly noticeable in these areas. The forests on Bamboutos have been reduced to isolated patches separated by cultivated grassland (pasture), crop fields or plantations. Habitat fragmentation can isolate subpopulations (Cushman, 2006) and diminish genetic diversity. Given that threatened, forestdependent species have not been found to utilize this habitat, grassland potentially acts as a barrier to dispersal. Pasture could even be an ecological sink because frogs entering grassland in an attempt to reach other forest patches risk desiccation and predation (e.g. Rothermel, 2004). This may partly explain the limited number of observations of the Critically Endangered L. axillaris, which was found in only one forest patch. Protection of this patch is urgent: although farmers had previously avoided cutting this particular patch, in October 2016 clearance had begun.

Cultivation on Bamboutos is causing visible soil erosion, probably resulting in run-off of nutrients, sediments and agrochemicals into lower streams where tadpoles of many frog species develop. Pesticides can be lethal to amphibians (Mann et al., 2009; Stechert et al., 2015) and we frequently observed them being applied on Mount Bamboutos. Because agrochemicals were used so widely, it was not possible to stratify the survey to understand their impacts. Potential future studies could include experimental challenges of frogs and their larvae to realistic concentrations of different agrochemicals (e.g. Stechert et al., 2015), although care would need to be taken to choose relevant 
study species that are not already threatened. An alternative way to study this would be to locate sites where agrochemicals are applied in a gradient of concentrations. Similarly, it is unclear how amphibians are affected by water abstraction for irrigation. This practice should be investigated further, given its likely effect on the depth, temperature and permanency of streams harbouring developing larvae.

Livestock grazing is prominent on Mount Bamboutos, and grassland is burned widely by livestock herders. This probably has a detrimental effect on montane endemic amphibians. Apart from indirect impacts of degradation of forest, water and prey, fire can kill less mobile amphibians (Schurbon \& Fauth, 2003). The presence of livestock potentially has adverse consequences for amphibians and their habitats through disturbance, trampling, water nutrient enrichment and changes in vegetation structure (Glenn et al., 1998). Practices to restrict or manage livestock grazing on Mount Bamboutos need to be investigated.

Mount Bamboutos is neither protected nor subject to any other conservation actions. Measures to reduce the rate of forest loss and degradation should be explored, such as the creation of a protected area consolidating the forest, possibly through the delegation of government and/or community forest organizations. Ex situ conservation of rarer species should be considered where extirpation is imminent, such as for L. axillaris. However, this requires knowledge of the ecological requirements of the target species, and sufficient founding stock (Tapley et al., 2015; Gratwicke et al., 2016). Involvement and support of local stakeholders are needed to secure the success of any conservation interventions. This includes investigating and adopting alternative farming strategies that are more sustainable and environmentally safe.

Several amphibian species on Mount Bamboutos have large proportions of their global range (c. $25 \%$ for species such as L. perreti, c. $50-100 \%$ for L. axillaris) on this mountain. The majority of these montane endemic species appears to be dependent on forest, and some endemic species have disappeared before their habitat requirements could be adequately assessed. Mount Bamboutos has undergone severe degradation that is set to continue. In the absence of official protection, strategies are needed to involve local communities in the process of conserving remnant forest and restoring degraded habitats.

Acknowledgements We are grateful to the Cameroon Herpetology Conservation Biology Foundation. AMTF was supported by The Rufford Foundation, Columbus Zoo and Idea Wild; TMD-B by the Royal Zoological Society of Scotland. Special thanks to Mark Wilkinson, Geraud Tasse, Idesse, Souleymane, Seydou, Djibril and volunteers for their assistance during this study.

Author contributions Study conception and design: AMTF, with contributions from LNG, JLT; data collection: AMTF, MMKN, TMD-B, WPTN; data analysis: TMD-B, AMTF; writing: AMTF, with assistance from TMD-B, LNG; project supervision: JLT. All authors reviewed and approved the final manuscript.

\section{Conflict of interest None.}

Ethical standards This research abided by the Oryx guidelines on ethical standards and the ethical guidelines of the British Herpetological Society (2017). Collecting amphibians during fieldwork was permitted by the Cameroon Ministry of Scientific Research and Innovation (13/MINRESI/B00/C00/C10/C10) and the Ministry of Forestry and Wildlife (629PRS/MINFOF/SG/DFAP/SDVEF/SC).

\section{References}

Akani, G.C., Politano, E. \& Luiselli, L. (2004) Amphibians recorded in forest swamp areas of the River Niger Delta (southeastern Nigeria), and the effects of habitat alteration from oil industry development on species richness and diversity. Applied Herpetology, 2, 1-22.

Amiet, J.-L. (1972) Description de cinq nouvelles espèces camerounaises de Cardioglossa (Amphibiens: Anoures). Biologia Gabonica, 8, 201-231.

Amiet, J.-L. (1977) Les Astylosternus du Cameroun (Amphibia, Anura, Astylosternidae). Annales de la Faculté des Sciences du Cameroun, Yaoundé, 23-24, 99-227.

Aмiet, J.-L. (1980) Révision du genre Leptodactylodon andersson (Amphibia, Anura, Astylosternidae). Annales de la Faculté des Sciences du Cameroun, Yaoundé, 27, 69-224.

Amiet, J-L. (2012) Les Rainettes du Cameroun (Amphibiens, Anoures). Édition J.-L. Amiet \& La Nef des Livres, Saint-Nazaire, France.

Anderson, M.J. (2001) A new method for non-parametric multivariate analysis of variance. Austral Ecology, 26, 32-46.

Barlow, J., Gardner, T.A., Louzada, J. \& Peres, C.A. (2010) Measuring the conservation value of tropical primary forest: the effect of occasional species on estimates of biodiversity uniqueness. PLOS ONE, 5, e9609.

Beebee, T.J.C. \& Griffiths, R.A. (2005) The amphibian decline crisis: a watershed for conservation biology? Biological Conservation, 125, 271-285.

Beniston, M., Fox, D.G., Adhikary, S., Andressen, R., Guisan, A., Holten, J. et al. (1996) Impacts of climate change on mountain regions. In Climate Change 1995: Impacts, Adaptations and Mitigation of Climate Change (eds R.T. Watson, M.C. Zinyowera, R.H. Moss \& D.J. Dokken), pp. 191-213. Cambridge University Press, Cambridge, UK.

Bergl, R.A., OAtes, J.F. \& Fotso, R. (2007) Distribution and protected area coverage of endemic taxa in West Africa's Biafran forests and highlands. Biological Conservation, 134, 195-208.

Böhm, M., Collen, B., Baillie, J.E.M., Bowles, P., Chanson, J., Cox, N., Hammerson, G. et al. (2013) The conservation status of the world's reptiles. Biological Conservation, 157, 372-385.

British Herpetological Society (2017) Ethical policy and guidelines. The Herpetological Bulletin, 141, 46-48.

BRITO, D. (2008) Amphibian conservation: are we on the right track? Biological Conservation, 141, 2912-2917.

Burgess, N.D., Balmford, A., Cordeiro, N.J., Fjelds ̊̊, J., Küper, W., RAнBвк, C. et al. (2007) Correlations among species distributions, human density and human infrastructure across the high biodiversity tropical mountains of Africa. Biological Conservation, 134, 164-177.

Clarke, K.R. (1993) Non-parametric multivariate analyses of changes in community structure. Australian Journal of Ecology, 18, 117-143. 
Crump, M.L. \& ScotT, JR, N.J. (1994) Visual encounter surveys. In Measuring and Monitoring Biological Diversity, Standard Method for Amphibians (eds W.R. Heyer, M.A. Donnelly, R.W. Mc Diarmid, A.C. Hayek \& M.S. Foster), pp. 84-92. Smithsonian Institution Press, Washington, DC, USA.

Cruz, D., Dawson, A.L. \& Blackburn, D.C. (2013) Description of the tadpoles of two Cameroonian frogs, Leptodactylodon axillaris and L. perreti (Anura: Arthroleptidae). African Journal of Herpetology, 62, 28-39.

Cushman, S.A. (2006) Effects of habitat loss and fragmentation on amphibians: a review and prospectus. Biological Conservation, 128, 231-240.

Doherty-Bone, T.M. (2017) African Amphibians and Climate Change: a Call to Vigilance. 17th African Amphibians Working Group Meeting, CSIR-Forestry Research Institute, Kumasi, Ghana.

Doherty-Bone, T.M. \& Gvoždík, V. (2017) The amphibians of Mount Oku, Cameroon: an updated species inventory and conservation review. ZooKeys, 643, 109-139.

Doherty-Bone, T.M., Ndifon, R.K., San Mauro, D., Wilkinson, M., Gonwouo, N.L. \& Gower, D.J. (2011) Systematics and ecology of the caecilian Crotaphatrema lamottei (Nussbaum) (Amphibia: Gymnophiona: Scolecomorphidae). Journal of Natural History, $45,827-841$.

Ernst, R., Linsenmair, K.E. \& Rödel, M.-O. (2006) Diversity erosion beyond the species level: dramatic loss of functional diversity after selective logging in two tropical amphibian communities. Biological Conservation, 133, 143-155.

Gardner, T.A., Barlow, J. \& Peres, C.A. (2007a) Paradox, presumption and pitfalls in conservation biology: the importance of habitat change for amphibians and reptiles. Biological Conservation, $138,166-179$.

Gardner, T.A., Fitzherbert, E.B., Drewes, R.C., Howell, K.M. \& CARo, T. (2007b) Spatial and temporal patterns of abundance and diversity of an East African leaf litter amphibian fauna. Biotropica, $39,105-113$.

Gartshore, M.E. (1986) The status of the montane herpetofauna of the Cameroon highlands. In Conservation of Cameroon Montane Forests (ed. S.N. Stuart), pp. 204-240. International Council for Bird Preservation, Cambridge, UK.

Glenn, N., Tate, K.W., Atwill, R. \& Bushnell, J. (1998) Water quality effect of rangeland beef cattle excrement. Rangelands, 20, 19-25.

Gountié Dedzo, M., Kamgang, P., Nuonfang, E., Zangmo Tefogoum, G., Kagou Dongmo, A. \& Nkouathio, D.G. (2013) Mapping and assessment of volcanic hazards related to the ignimbritic eruption by AMS in Bambouto volcano (Cameroon Volcanic Line). The Open Geology Journal, 7, 1-13.

Gratwicke, B., Ross, H., Batista, A., Chaves, G., Crawford, A.J., Elizondo, L. et al. (2016) Evaluating the probability of avoiding disease-related extinctions of Panamanian amphibians through captive breeding programs. Animal Conservation, 19, 324-336.

Herrmann, H.W., Böhme, W., Herrmann, P.A., Plath, M., Schmitz, A. \& Solbach, M. (2005) African biodiversity hotspots: the amphibians of Mt Nlonako, Cameroon. Salamandra, 41, 61-81.

Herrmann, H.W., Schmitz, A., Herrmann, P.A. \& Böhme, W. (2007) Amphibians and reptiles of the Tchabal Mbabo Moutains, Adamaoua Plateau, Cameroon. Bonner Zoologische Beiträge, $55,27-35$.

Hillers, A., Veith, M. \& Rödel, M.-O. (2008) Effects of forest fragmentation and habitat degradation on West African leaf-litter frogs. Conservation Biology, 3, 762-772.

Hirschfeld, M., Blackburn, D.C., Doherty-Bone, T.M., Gonwouo, L.N., Ghose, S. \& RöDel, M.-O. (2016) Dramatic declines of montane frogs in a central African biodiversity hotspot. PLOS ONE, 11, e0155129.

IUCN (2017) The Red List of Threatened Species. Http://www. iucnredlist.org [accessed 4 April 2018].

Kengni, L., Tekoudjou, H., Pamo Tedonkeng, E., Tankou, C., Mubeteneh, L.Y. \& Probst, J.-L. (2009) Rainfall variability along the southern flank of the Bambouto Mountain (West-Cameroon). Journal of the Cameroon Academy of Sciences, 8, 45-52.

Kouete, M.T., Wilkinson, M. \& Gower, D.J. (2012) First reproductive observations for Herpele Peters, 1880 (Amphibia: Gymnophiona: Herpelidae): evidence of extended parental care and maternal dermatophagy in H. squalostoma (Stutchbury, 1836). International Scholarly Research Notices Zoology, 2012, 1-7.

Largen, M.J. \& Spawls, S. (2010) The Amphibians and Reptiles of Ethiopia and Eritrea. Edition Chimaira, Frankfurt am Main, Germany.

Lawson, D.P. \& Klemens, M.W. (2001) Herpetofauna of the African rain forest: overview and recommendations for conservation. In African Rainforest Ecology and Conservation (eds W. Weber, L.J.T. White, A. Vedder \& L. Naughton-Treves), pp. 291-307. Yale University Press, London, UK.

Mann, R.M., Hyne, R.V., Choung, C.B., \& Wilson, S.P. (2009) Amphibians and agricultural chemicals: review of the risks in a complex environment. Environmental Pollution, $157,2903-2927$.

Mazerolle, M.J. (2006) Improving data analysis in herpetology: using Akaike's information criterion (AIC) to assess the strength of biological hypotheses. Amphibia-Reptilia, 27, 169-180.

Mertens, R. (1968) Zur Kenntnis der Herpetofauna von Kamerun und Fernando Poo. Bonner Zoologische Beiträge, 19, 69-84.

Ofori-Boateng, C., Oduro, W., Hillers, A., Norris, K., Oppong, S.K., Adum, G.B. \& RöDel, M.-O. (2013) Differences in the effects of selective logging on amphibian assemblages in three West African forest types. Biotropica, 1, 94-101.

O'hara, R.B. \& Kotze, D.J. (2010) Do not log-transform count data. Methods in Ecology and Evolution, 1, 118-122.

Perret, J.-L. (1966) Les Amphibiens du Cameroun. Zoologische Jahrbücher für Systematik, 8, 289-464.

PeRRET, J.-L. (1972) Les espèces des genres Wolterstorffina et Nectophrynoides d'afrique. Annales de la Faculté des Sciences du Cameroun, 11, 93-119.

Poynton, J.C., Loader, S.P., Sherratt, E. \& Clarke, B.T. (2006) Amphibian diversity in East African biodiversity hotspots: altitudinal and latitudinal patterns. Biodiversity and Conservation, 16, 1103-1118.

R CORE TEAM (2016) R: a Language and Environment for Statistical Computing. R Foundation for Statistical Computing, Vienna, Austria. Http://www.R-project.org [accessed 30 July 2014].

Riemann, J.C., Ndriantsoa, S.H., Rödel, M.-O. \& Glos, J. (2017) Functional diversity in a fragmented landscape-habitat alterations affect functional trait composition of frog assemblages in Madagascar. Global Ecology and Conservation, 10, 173-183.

RöDel, M.-O. \& ERnst, R. (2004) Measuring and monitoring amphibian diversity in tropical forests. I. An evaluation of methods with recommendations for standardization. Ecotropica, 10, 1-14.

Rothermel, B.B. (2004) Migratory success of juveniles: a potential constraint on connectivity for pond-breeding amphibians. Ecological Applications, 14, 1535-1546.

Sandberger-Loua, L., Doumbia, J. \& Rödel, M.-O. (2016) Conserving the unique to save the diverse-identifying key environmental determinants for the persistence of the viviparous 
Nimba toad in a West African World Heritage Site. Biological Conservation, 198, 15-21.

Schiesari, L., Grillitsch, B. \& Grillitsch, H. (2007) Biogeographic biases in research and their consequences for linking amphibian declines to pollution. Conservation Biology, 21, 465-471.

Schurbon, J.M. \& Fauth, J.E. (2003) Effects of prescribed burning on amphibian diversity in a southeastern U.S. National Forest. Conservation Biology, 17, 1338-1349.

Stechert, C., Kolb, M., Rödel, M.-O. \& Bahadir, M. (2015) Effects of insecticide formulations used in cotton cultivation in West Africa on the development of flat-backed toad tadpoles (Amietophrynus maculatus). Environmental Science and Pollution Research, 22, 2574-2583.
Stuart, S.N., Chanson, J.S., Cox, N.A., Young, B.E., Rodrigues, A.S.L., Fischman, D.L., Waller, R.W. (2004) Status and trends of amphibian declines and extinctions worldwide. Science, 306, $1783-1786$.

Tapley, B., Bradfield, K.S., Michaels, C. \& Bungard, M. (2015) Amphibians and conservation breeding programmes: do all threatened amphibians belong on the ark? Biodiversity and Conservation, 24, 2625-2646.

Wilkinson, M., Múller, H. \& Gower, D.J. (2006) On Herpele multiplicata (Amphibia: Gymnophiona: Caeciliidae). African Journal of Herpetology, 52, 119-122.

Zimkus, B.M. \& GvožDí, V. (2013) Sky Islands of the Cameroon Volcanic Line: a diversification hot spot for puddle frogs (Phrynobatrachidae: Phrynobatrachus). Zoologica Scripta, 42, 591-611. 